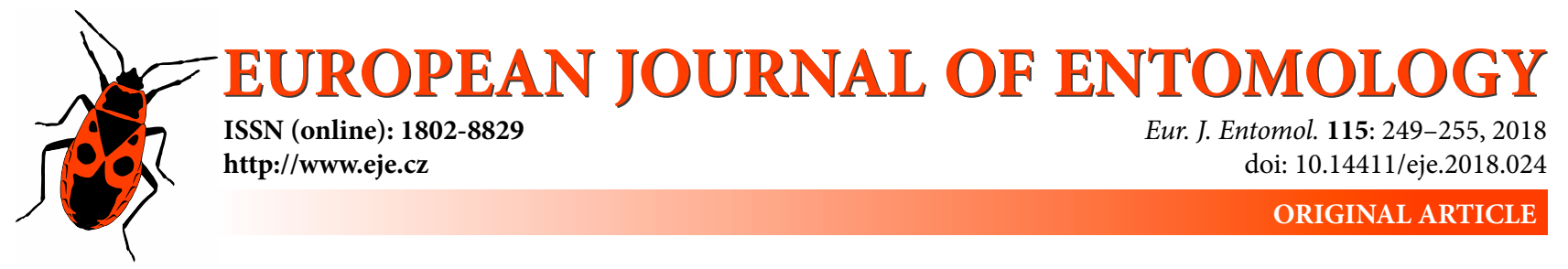

\title{
Weather-dependent fluctuations in the abundance of the oak processionary moth, Thaumetopoea processionea (Lepidoptera: Notodontidae)
}

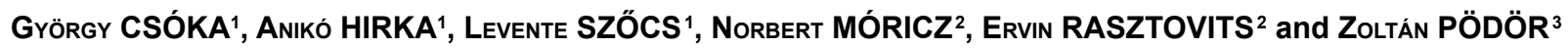 \\ ${ }^{1}$ NARIC Forest Research Institute, Department of Forest Protection, Hegyalja str. 18., 3232 Mátrafüred, Hungary; \\ e-mails: csokagy@erti.hu, hirkaa@erti.hu, szocsl@erti.hu \\ ${ }^{2}$ NARIC Forest Research Institute, Department of Ecology and Silviculture, Paprét 17., 9400 Sopron, Hungary; \\ e-mails: moriczn@erti.hu, rasztovitse@erti.hu \\ ${ }^{3}$ Institute of Informatics and Economics, Simonyi Károly Faculty of Engineering Wood Sciences and Applied Arts, \\ University of Sopron, Bajcsy-Zsilinszky str. 9., 9400 Sopron, Hungary; e-mail: podor@inf.uni-sopron.hu
}

Key words. Lepidoptera, Notodontidae, Thaumetopoea processionea, light trap, data mining, population fluctuation, Moraneffect, drought, oak defoliator, CReMIT-analysis

\begin{abstract}
Population fluctuations of the well-known oak defoliator, the oak processionary moth (Thaumetopoea processionea L.), were studied using light trap data and basic meteorological parameters (monthly average temperatures, and precipitation) at three locations in Western Hungary over a period of 15 years (1988-2012). The fluctuations in the numbers caught by the three traps were strongly synchronized. One possible explanation for this synchrony may be similar weather at the three trapping locations. Cyclic Reverse Moving Interval Techniques (CReMIT) were used to define the period of time in a year that most strongly influences the catches. For this period, we defined a species specific aridity index for Thaumetopoea processionea (THAU-index). This index explains $54.8-68.9 \%$ of the variation in the yearly catches, which indicates that aridity, particularly in the May-July period was the major determinant of population fluctuations. Our results predict an increasing future risk of Oak Processionary Moth (OPM) outbreaks and further spread if the frequency of severe spring/summer droughts increases with global warming.
\end{abstract}

\section{INTRODUCTION}

The changing climate, as in other parts of Europe and the world, is significantly affecting Hungarian forests (Borovics \& Mátyás, 2013; Hlásny et al., 2014; Rasztovits et al., 2014). Forest insects are also influenced directly and indirectly in many different and often interacting ways (Lakatos \& Molnár, 2009; Robinet \& Roques, 2010). Climate change therefore may for example cause range expansion (Vanhanen et al., 2007; Battisti, 2008; Jepsen et al., 2008; Battisti \& Larsson, 2015; Battisti et al., 2017), either decrease or increase the number of generations in multivoltine species (Ayres \& Lombardero, 2000; Jönsson et al., 2009) and alter their interactions with their host plants (Pelini et al., 2009; Robinet \& Roques, 2010) and natural enemies (Jeffs \& Lewis, 2013; Kalinkat \& Rall, 2015). The summation of these different effects can have a significant effect on population fluctuations, outbreaks and damage by forest insects (Mattson \& Haack, 1987; Leskó et al., 1995, 1998; Csóka, 1997; Rouault et al., 2006; Dobbertin et al., 2007; Jactel et al., 2012; Klapwijk et al., 2013; Hlásny et al., 2015).
Processionary moths (Lepidoptera: Notodontidae), particularly Thaumetopoea pityocampa (Denis \& Schiffermüller, 1775) have recently been intensely studied throughout Europe due to range expansion as a consequence of climate change (Pimentel et al., 2006, 2011; Hoch et al., 2009; Straw \& Williams, 2013; Roques et al., 2015; Mirchev et al., 2016). The other species of the genus that has undergone a considerable expansion in its range is the OPM - oak processionary moth Thaumetopoea processionea (Linnaeus, 1758). This species is a pest of oaks in the South Eastern part of Europe, but rather rare in Western Europe. In the last 2-3 decades it has spread to Northwest Europe and the Middle East (Groenen, 2010; Groenen \& Meurisse, 2012). It was rediscovered in Belgium in 1970 after a 65 year absence (Groenen, 2010) and appeared in the Netherlands in large numbers after more than 100 years (Stigter \& Romeijn, 1992). Blaik et al. (2011) report the rediscovery of this species in Northwest Poland after an absence ca. 100 years. Groenen \& Meurisse (2012) consider these to be examples of recolonizations rather than real area expansions. However, males of the species were caught both in Denmark (Skule \& Vilhelmsem, 1997) and 
Sweden (Lövgren \& Dalsved, 2005), two countries where this species is not previously recorded. Of course a contribution of international trade cannot be excluded from these processes. This is the case in the UK, where the species appeared for the first time in 2006 as result of plant trade rather than natural range expansion (Baker et al., 2009; Mindlin et al., 2012).

Greater than the effect on forest health, the spread and outbreaks of OPM increased international awareness of the effect of its urticating hairs on human health (Maier et al., 2004; Gottschling \& Meyer, 2006; Green, 2015; Battisti et al., 2017). The human and animal health related importance is well known in Hungary but are normally less frequent and severe than they are likely to be in the Netherlands or Belgium, since OPM populations in Hungary are mainly found in forests rather than in city parks or inhabited areas.

OPM is native to Hungary and the damage it causes has been reported from time to time since the late $19^{\text {th }}$ century (Szontagh, 1976; Hirka et al., 2011). It is one of the "Top 12" forest pests in Hungary (Hirka et al., 2011), but not classified as a serious pest. The long term (1961-2012) measure of the area damaged per year is 808 hectares countrywide. The average damage for the period 1998-2012 (time span of the present study) is 1,672 ha/year, which is considerably greater than the long term average. The damage caused by OPM peaked in 2004 with a total of 4,270 ha damaged countrywide (source: Forest Damage Database of the Forest Research Institute). OPM's life history in Hungary is similar to its life history in other European countries. The adults normally fly from late July till mid-September, with a peak in August, but females can sometimes be found as late as early December (Gy. Csóka, unpubl.). Both males and females are capable of flying, and are attracted to artificial light, therefore can be efficiently caught and monitored by light traps.

Small and scattered local outbreaks are reported in many different regions of Hungary, where its main host, Turkey oak (Quercus cerris) is abundant. Defoliation is also recorded for other native oaks (Quercus robur, Q. petraea and $Q$. pubescens). OPM is a thermo- and heliophil species (Szontagh, 1976; Hirka et al., 2011). It does not always behave as a classic outbreak species, as it some places it remains abundant for long periods, neither increasing or collapsing suddenly. Defoliation by this species rarely exceeds $50 \%$ at the scale of a stand, unlike the gypsy moth (Lymantria dispar). which can completely defoliate large areas (Mcmanus \& Csóka, 2007; Hirka et al., 2011). The high density foci of OPM are rather small and scattered, and do not form a large continuous area. However, there has been a recent expansion of these high density foci at some places.

Understanding the link between climate change and population trends of forest insects and providing reliable forecasts for the future is a major challenge. The main aim of the present study is to quantify the effect of weather on the population fluctuations of OPM. We hypothesize that the weather conditions (temperature and precipitation) during the larval period of OPM have a significant effect on

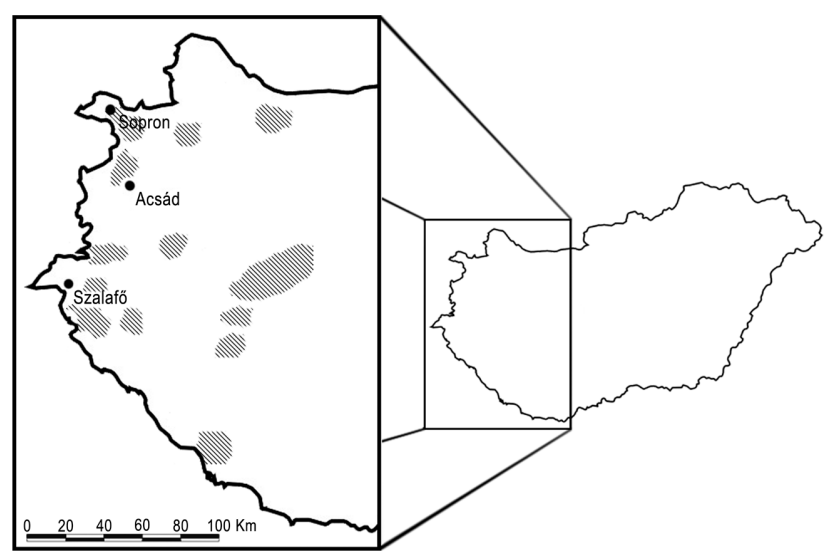

Fig. 1. Locations of the three light traps used in this study. (Shaded spots indicate high density populations of OPM.)

the population fluctuations, as already suggested in several earlier papers (Klapwijk et al., 2013; Wagenhoff \& Veit, 2011; Wagenhoff et al., 2013, 2014). We assume that high spring temperatures have positive effects on the populations as under these conditions development is faster and mortality lower. Conversely rain fall in spring is assumed to have a negative effect due to slower development and higher mortality (both directly and indirectly due to pathogens). We test this hypothesis by determining the relationships between light trap catches, as a measure of population fluctuation, and meteorological variables as described below.

\section{MATERIAL AND METHODS}

\section{The data used}

We used yearly OPM catches of 3 light traps (Fig. 1 and Table 1) over a period of 15 years (1998-2012) to quantify the population fluctuations. This period of time is the longest period during which all 3 light traps were operational. These light traps belong to the Forestry Light Trap Network run by the Hungarian Forest Research Institute since the early 1960s. The pairwise distances between the trap locations are as follows: Acsád-Sopron: 41 km; Acsád-Szalafö: $57 \mathrm{~km}$; Sopron-Szalafö: $91 \mathrm{~km}$. The traps are located in old forests, therefore the stand conditions did not change very much during the 15 year study period. The standardized light traps are equipped with $125 \mathrm{~W}$ mercury bulbs and operated continuously between 1st March and the end of December. The traps are emptied daily and the species of Macrolepidoptera identified (Hirka et al., 2011). The data collected using light traps might be used for many different purposes, i.e. forecasting outbreaks, faunistic studies, flight phenology, diversity trends, etc. Light traps that operate continuously during a whole season at the same place over a long period, are excellent tools for following the population fluctuations of insects attracted to artificial light (Tallós, 1966; Szontagh, 1975, 1968; Hirka et al., 2011).

Table 1. Basic information on the light traps used in this study.

\begin{tabular}{lcc}
\hline Location & WGS 84 coordinates & Forest type around the trap \\
\hline \multirow{2}{*}{ Acsád } & $47^{\circ} 18^{\prime} 56.4^{\prime \prime} \mathrm{N}$ & Mixed broadleaved forest \\
& $16^{\circ} 43^{\prime} 11.8^{\prime \prime} \mathrm{E}$ & with dominance of $Q$. cerris \\
\multirow{2}{*}{ Sopron } & $47^{\circ} 39^{\prime} 51.5^{\prime \prime} \mathrm{N}$ & Mixed broadleaved forest \\
& $16^{\circ} 33^{\prime} 14.5^{\prime \prime} \mathrm{E}$ & with dominance of $Q$. petraea \\
\multirow{2}{*}{ Szalafó } & $46^{\circ} 51^{\prime} 19.3^{\prime \prime} \mathrm{N}$ & Mixed broadleaved forest \\
& $16^{\circ} 22^{\prime} 33.4^{\prime \prime} \mathrm{E}$ & with dominance of $Q$. robur \\
\hline
\end{tabular}


Although the daily light trap catches are influenced by many environmental factors (temperature, wind rain, clouds, moon phase) (Yela \& Holyoak, 1997; Nowinszky et al., 2010; Nowinszky \& Puskás, 2017) they are good for monitoring long term population fluctuations if pooled together for a whole season, since the short term environmental effects are neutralized if collected over a long period of time (Raimondo et al., 2004).

Unfortunately, there are no reliable long term quantitative datasets for the area defoliated by OPM in the vicinity of traps, but the areas with regularly high population densities and moderate defoliation are known (see on Fig. 1).

The meteorological variables used in the analysis were interpolated as described in detail below. We used monthly average temperatures and monthly total precipitation as primary data. Monthly precipitation data was obtained from the hydrological annals, published by the Water Resources Research Centre (VITUKI). Additional data was obtained from the Hungarian Meteorological Service (OMSz). The dataset included 608 monthly rain gauge recordings for the years 1997-2012 in Hungary. The number and the location of the rain gauges changed frequently in the given period, thus only stations with a continuous data series were included in the database. To achieve this, a representative radius of $5 \mathrm{~km}$ was set for each station. If translocation occurred within this radius, time series were considered continuous. Raw rain gauge records underwent a series of quality tests to identify obvious anomalies and remove false values. Precipitation maps were created using the kriging interpolation method. Kriging is a geostatistical gridding method that has proved useful and been applied extensively for the interpolation of climate data (Dingman et al., 1988; Garen et al., 1994; Hevesi et al., 1992). The reliability of the precipitation maps was assessed using a crossvalidation method. The mean of the deviations from the observed values was $49.4 \mathrm{~mm}$, which is $8.2 \%$ of the observed mean annual precipitation in Hungary.

Mean monthly air temperature recorded at a height of 2 meters was obtained from the monthly weather reports published by the Hungarian Meteorological Service (OMSz). The temperature dataset included 31 weather stations in Hungary for the period of 1997-2012. Temperature maps were created using the same kriging interpolation method. The dependence of temperature on altitude was taken into account by applying a monthly vertical gradient. The effect of slope and aspect on air temperature was corrected for by using the solar radiation analysis tool in the ArcGIS software (Yang et al., 2007).

\section{Analyses}

(1) We used the correlation matrix of the yearly OPM catches by the three light traps to compare the temporal patterns in the population fluctuations at the different locations. We checked whether there is a linear trend in the yearly catches of the three traps for the period 1998-2012 (Student t-test, $\alpha=0.05, \mathrm{DF}=13$ ).

(2) We used CReMIT (Cyclic Reverse Moving Interval Technics) to define the periods within years that had the strongest effect on the catches (Pödör et al., 2014). CReMIT is a data-mining method that helped us test our main hypothesis. CReMIT creates all possible aggregated datasets in a time series to sphere the examination possibilities. The maximum length (ML) and time shifting (TS) of the derived variables are defined by the user. The CReMIT method combines the evolutionary and moving interval techniques to create all possible derived time series according to the above mentioned two parameters. For example, if we examine the monthly temperature time series in which ML is 3 , TS is 2 and the starting point is 11.2017 , than we create, in addition to the basic monthly data, the values for every year: average temperature in June, June-July, June-Aug, July, July-Aug, July-Sep,
Aug, Aug-Sep, Aug-Oct, Sep, Sep-Oct, Sep-Nov, Oct, Oct-Nov and Nov. The created time series includes both values for single months and, aggregated time series.

This method provides the average temperatures and sum of precipitation for all the given intervals. These secondary explanatory variables can be correlated with the response variable (light trap catching data) and so expand the scope of the study. The strengths of the correlations with these secondary variables helps in choosing the time windows that have the strongest effects on the response variable. In our analyses all months in the created secondary time periods were given the same weight (1). With different weighting of the different months, the correlations and $\mathrm{r}-$ values could have been greater. However, we wanted to keep the analyses relatively simple in order to avoid speculative explanations of the results.

The lengths of time windows spanned from October to the following July. We decided to exclude both temperature and precipitation for August and September from the analysis. This is because weather conditions in these two months (main flight period) may directly influence the light trap catches (less flight activity, etc.), as demonstrated by Bonsignore \& Manti (2013) for Thaumetopoea pityocampa.

In order to decrease the risks of a misleading interpretation, we did not include August and September (the main flight period of OPM) in the THAU-index. In addition, we separately checked the direct influence of weather conditions (temperature and precipitation) in these two months on the yearly catches.

(3) Based on the results of the CReMIT derived time series analysis, we intended to create a species specific variable for OPM. The time windows with the highest explanatory power for all three traps were incorporated in a species specific index called "THAU", which is based on the genus name of OPM. The definition of THAU is given in the "Results" section.

(4) We correlated the yearly values of THAU for the three trap locations. We checked whether there is a linear trend in the yearly THAU values calculated for the three trap locations for the period 1998-2012. Then yearly values of the THAU index (as explanatory variable) were correlated with the yearly catches of the light traps (as response variable) using linear regression (Student t-test, $\alpha=0.05, \mathrm{DF}=13)$.

(5) We also analyzed the delayed effect of the THAU value of the previous year on a given year. In addition, the cumulative effect of a given year's and previous year's THAU was also analyzed.

\section{RESULTS}

\section{Correlations and trend analysis of the yearly OPM catches of the three traps}

The yearly OPM catches of the three traps are given in supplementary Table S1. There are significant positive correlations between yearly OPM catches of all three traps ( $\mathrm{r}$ values and levels of significance, $*=95 \%$; $* *=99 \%)$ : Ac-

Table 2. Significance levels for the correlations between average temperatures in different time windows and yearly catches. I-XII - months; ns - not significant; * - significant at 95\% level; ${ }^{*}$ - significant at $99 \%$ level.

\begin{tabular}{lcccc}
\hline From & To & Acsád & Sopron & Szalafö \\
\hline $\mathrm{T}_{I V}$ & $\mathrm{~T}_{\mathrm{VI}}$ & $*$ & $\mathrm{~ns}$ & $\mathrm{~ns}$ \\
$\mathrm{~T}_{I V}$ & $\mathrm{~T}_{\mathrm{VII}}$ & $* *$ & $\mathrm{~ns}$ & $\mathrm{~ns}$ \\
$\mathrm{~T}_{\mathrm{V}}$ & $\mathrm{T}_{\mathrm{VII}}$ & $* *$ & $* *$ & ${ }^{* *}$ \\
$\mathrm{~T}_{\mathrm{V}}$ & $\mathrm{T}_{\mathrm{VIII}}$ & $* *$ & $*$ & $*$ \\
$\mathrm{~T}_{\mathrm{VI}}$ & $\mathrm{T}_{\mathrm{VII}}$ & $*$ & $*$ & $*$ \\
\hline
\end{tabular}




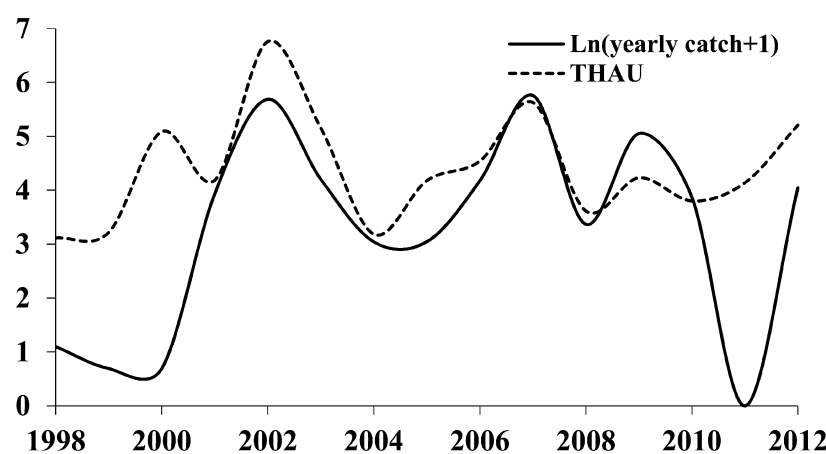

Fig. 2. Yearly values of THAU and the OPM catches at Acsád between 1998 and 2012.

sád-Sopron: 0.65*; Acsád-Szalafő: 0.53*; Sopron-Szalafő: $0.97 * *$.

No significant linear trend in yearly catches was found for any of the traps for the given period (1998-2012).

\section{CReMIT analysis - periods in a year when temperature and precipitation had the greatest effect}

Average temperature in the period May-July had the greatest explanatory power (Table 2). No strong explanatory power of other time windows was found for temperature. The analysis of precipitation gave a different result. Precipitation in the period from October to July had the greatest explanatory power (Table 3 ).

There was no significant $(\mathrm{p}<0.05)$ influence of weather (monthly precipitation and monthly average temperature) during the flight period (August and September separately and also these two months summed together) on the yearly catches. Therefore, we conclude that weather conditions are a far more important in synchronizing remote populations in terms of larval and pupal development than in determining the flight period.

\section{Definition of THAU}

Based on the results presented above we defined the THAU as:

$T H A U=100 \cdot \frac{T_{V-V I I}}{P_{X-V I I}}$

where $T_{V-V I I}=$ average temperature in the period May-July $\left(\mathrm{C}^{\circ}\right)$ and $P_{X-V I I}=$ summed precipitation between October and the following July ( $\mathrm{mm})$.

The explanatory power of THAU is greater than the explanatory power of either temperature or precipitation,

Table 3. Significance levels for the correlations between summed precipitation in different time windows and yearly catches. I-XII - months; ns - not significant; ${ }^{*}$ - significant at 95\% level; ${ }^{* *}$ - significant at $99 \%$ level.

\begin{tabular}{lllll}
\hline $\mathrm{P}_{\mathrm{XI}}$ & $\mathrm{P}_{I I}$ & $\mathrm{~ns}$ & $\mathrm{~ns}$ & $\mathrm{~ns}$ \\
$\mathrm{P}_{\mathrm{X}}$ & $\mathrm{P}_{\mathrm{VI}}$ & $*$ & $*$ & $* *$ \\
$\mathrm{P}_{\mathrm{X}}$ & $\mathrm{P}_{\mathrm{VII}}$ & $* *$ & $*$ & $* *$ \\
$\mathrm{P}_{I V}$ & $\mathrm{P}_{\mathrm{VI}}$ & $\mathrm{ns}$ & $\mathrm{ns}$ & $\mathrm{ns}$ \\
$\mathrm{P}_{I V}$ & $\mathrm{P}_{\mathrm{VII}}$ & $\mathrm{ns}$ & $\mathrm{ns}$ & $\mathrm{ns}$ \\
$\mathrm{P}_{\mathrm{V}}$ & $\mathrm{P}_{\mathrm{VII}}$ & $\mathrm{ns}$ & $\mathrm{ns}$ & $\mathrm{ns}$ \\
$\mathrm{P}_{\mathrm{V}}$ & $\mathrm{P}_{\mathrm{VIII}}$ & $\mathrm{ns}$ & $\mathrm{ns}$ & $\mathrm{ns}$ \\
$\mathrm{P}_{\mathrm{VI}}$ & $\mathrm{P}_{\mathrm{VII}}$ & $\mathrm{ns}$ & $\mathrm{ns}$ & $\mathrm{ns}$ \\
\hline
\end{tabular}

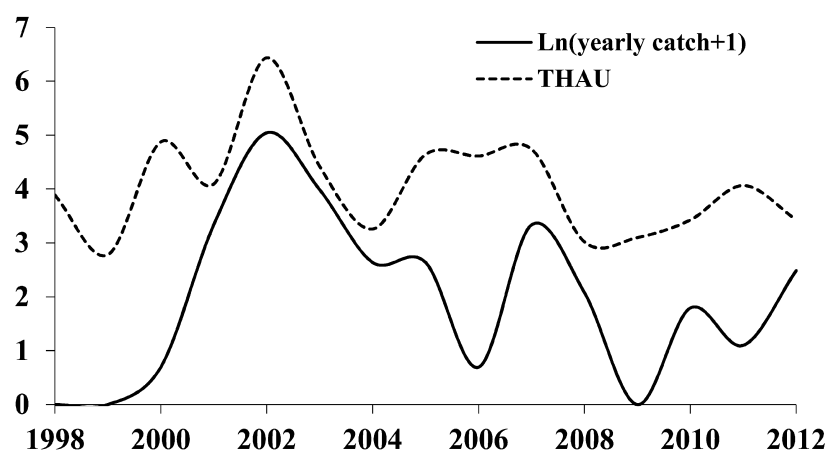

Fig. 3. Yearly values of THAU and the OPM catches at Sopron between 1998 and 2012.

which indicates the importance of combining the effect of these two factors.

\section{Correlations and trend analysis of the yearly THAU values of the three traps}

The THAU values are highly significantly $(\mathrm{p}<0.01)$ positively correlated among all 3 traps (Acsád-Sopron: 0.80; Acsád-Szalafö: 0.85; Sopron-Szalafö: 0.78). There were no significant linear trends in the yearly catches of any of the traps or the yearly THAU values of any of the trap locations for 1998-2012 period.

\section{Effects of THAU on the yearly catches}

The THAU values for the time windows mentioned above were highly significantly $(\mathrm{p}<0.01)$ positively correlated with the yearly catches for all three traps (Table 4). A year's THAU value explained $54.8-68.9 \%$ of the variation in the yearly catches, indicating that aridity is one of the major factors influencing population fluctuations. The yearly values of the THAU and the trap catches (after "In" transformation) are given in Figs 2-4.

The THAU values of the previous year are not significantly correlated with the yearly catches. The average THAU values of a particular year and the previous year were highly significantly $(\mathrm{p}<0.01)$ correlated for two traps (Sopron, Szalafö) and significantly so $(0.01<\mathrm{p}<0.05)$ for Acsád.

\section{DISCUSSION}

The strong positive correlation between the yearly catches of the three traps show evident and strong synchrony in the population fluctuations at the three spatially rather remote locations. It is similar to the "Moran-effect", when populations of a given species are synchronized by synchronous stochastic effects, for example, weather (Moran, 1953; Liebhold et al., 2004; Hudson et al., 2006; Liebhold

Table 4. Levels of significance for the correlations between THAU (as the explanatory) and yearly catch (as response variable) for different time periods at the 3 trap locations. * - significant at $95 \%$; ** - significant at 99\%; "a" year - actual year, "p" year - previous year.

\begin{tabular}{|c|c|c|c|}
\hline Period / Light trap & Acsád & Soprc & zalafö \\
\hline THAU for "a" year & ** & ** & ** \\
\hline THAU for "p" year & ns & ns & ns \\
\hline THAU for the average of "a" and "p" year & ns & ** & ** \\
\hline
\end{tabular}




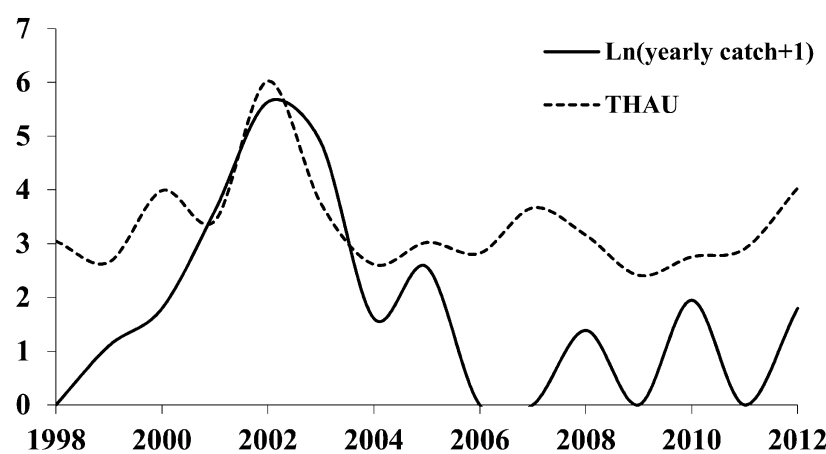

Fig. 4. Yearly values of THAU and the OPM catches at Szalafö between 1998 and 2012.

et al., 2006; Allstadt et al., 2015; Chevalier et al., 2015). Similar regional synchrony is demonstrated for $T$. pityocampa in France by (Li et al., 2015), but in this case low winter temperatures played the key role.

It should be mentioned that caution is needed when studying population fluctuations/synchrony using light trap catch data, simply because light trap catches are sensitive to weather conditions (Nowinszky \& Puskás, 2017). Therefore, the analysis may sometimes detect synchrony between light trap catches rather than synchrony of population fluctuations, as mentioned by Bonsignore \& Manti (2013) for T. pityocampa. This influence is much weaker over a long period (several weeks or even months) covering the whole flight season. Therefore, only light traps operational for long periods covering the whole flight period of a given species provide suitable time series for this kind of population study.

Unfortunately, there are no reliable defoliation data from the close vicinity of the trap locations that would allow us to search for a correlation between the light trap catches and the incidence of defoliation. However, there are significant positive correlations between light trap catches and defoliation for several important oak defoliating Lepidoptera, such as Lymantria dispar (Leskó et al., 1994), Euproctis chrysorrhoea (Linnaeus, 1758) (Leskó et al., 1995), Malacosoma neustria (Linnaeus, 1758) (Leskó et al., 1997) and Operophtera brumata (Linnaeus, 1758) (Leskó et al., 1999).

The influence of average temperature in the different time windows recorded in this study differs from that previously reported (Wagenhoff \& Veit, 2011; Klapwijk et al., 2013). The highest explanatory power was recorded for the May to July period. Taking April temperature into account only had a significant effect at one of the three locations (Acsád). Therefore, we excluded it, although several papers (Wagenhoff \& Veit, 2011; Meurisse et al., 2012; Klapwijk et al., 2013) mention that early spring (March and April) temperatures may influence populations due to their direct effect on larval survival and in disrupting the synchrony between budburst and egg hatch. However, the effect of this desynchronization is quite plastic, since young larvae may survive 2-3 weeks of starvation (Wagenhoff et al., 2013) and bud burst occurs earlier following mild winters and in warm early springs (Wagenhoff et al., 2014). The positive effect of temperature in the main larval feeding period is likely to be due to faster development shortening their exposure to both abiotic (i.e. rain) and biotic mortality factors (parasitoids and predators) and providing less favourable conditions for pathogens.

Precipitation (just like temperature) may also have both direct and indirect effects on population fluctuations. The time window with the greatest explanatory power was that from October to the following July (10 months). The importance of this rather long time window may be due to several different, but interacting factors. The most evident is the effect of spring precipitation on the mortality of the larvae in May and June and of the pupa in June and July. Wagenhoff \& Veit (2011) also mention that a wet spring may prevent an outbreak of OPM. In addition, direct mortality caused by rain in May and June, as a high rainfall then may increase the time it takes larvae to complete their development and thus the period they are exposed to other mortality factors (parasitoids, predators, entomopathogenic fungi, etc.). In addition, precipitation summed over a long period (from October to the follow July) has a positive effect on the physiological conditions of the host trees resulting in a more efficient induced defense against caterpillars.

It should be mentioned that there are considerable discrepancies between the OPM numbers predicted by two traps (Sopron and Szalafö) for the period 2006 to 2012. One possible reason is that in some years several factors, other than weather (parasitoids, pathogens, etc.), may play a significant role in the fluctuation of OPM populations.

The positive but insignificant correlations between the previous year's THAU index and yearly catches indicates there may be a direct effect of weather on population fluctuations. The average THAU values for a given and previous years explained less variation than the given year values, again supporting a stronger direct (within a year) effect of weather on the population fluctuations of OPM.

AUTHOR CONTRIBUTION STATEMENT. GyCs and AH developed the idea and wrote the manuscript. LSz identified the moths and contributed to manuscript. NM and ER: interpolation of meteorological data. ZP: CReMIT analysis, statistics. All authors read and approved the manuscript.

ACKNOWLEDGEMENT. This study was supported by the Agrárklíma.2 VKSZ_12-1-2013-0034 project sponsored by the Hungarian State and the National Research, Development and Innovation Fund.

CONFLICT OF INTEREST. The authors declare that they have no conflict of interest.

\section{REFERENCES}

Allstadt A.J., Liebhold A.M., Johnson D.M., Davis R.E. \& HAYNES K.J. 2015: Temporal variation in the synchrony of weather and its consequences for spatiotemporal population dynamics. - Ecology 96: 2935-2946.

Ayres M.P. \& Lombardero M.J. 2000: Assessing the consequences of global change for forest disturbance from herbivores and pathogens. - Sci. Total Environ. 262: 263-286.

Baker R., Caffier D., Choiseul J.W., Clerce P. de, Gerowitt B., Karadjova O.E., Lövei G., Oude A., Makowski D., Man- 
ceau C., Manici L., Perdikis D., Porta A., Schans J., Schrader G., Steffek R., Strömberg A., Tillikkala K., Lenteren C. van \& Vloutoglou I. 2009: Evaluation of a pest risk analysis on Thaumetopoea processionea L., the oak processionary moth, prepared by the UK and extension of its scope to the EU territory. - EFSA J. 1195: 1-64.

Battisti A. 2008: Forests and climate change - lessons from insects. - iForest-Biogeosci. Forestry 1: 1-5.

BAtTisti A. \& LARsson S. 2015: Climate change and insect pest distribution range. In Björkman C. \& Niemelä P. (eds): Climate Change and Insect Pests. CABI, Wallingford, pp. 1-15.

Battisti A., Larsson S. \& Roques A. 2017: Processionary moths and associated urtication risk: global change-driven effects. Annu. Rev. Entomol. 62: 323-342.

Blaik T., Malkiewicz A. \& Wasala R. 2011: Rediscovery and remarks on occurrence of Thaumetopoea processionea (Linnaeus, 1758) (Lepidoptera: Notodontidae: Thaumetopoeinae) in Poland. - Wiadom. Entomol. 30: 246-256.

Bonsignore C.P. \& MANTI F. 2013: Influence of habitat and climate on the capture of male pine processionary moths. - Bull. Insectol. 66: 27-34.

Borovics A. \& MÁtYÁs Cs. 2013: Decline of genetic diversity of sessile oak at the retracting (xeric) limits. - Ann. For. Sci. 70: 835-844.

Chevalier M., Laffaille P., Ferdy J.B. \& Grenouillet G. 2015: Measurements of spatial population synchrony: influence of time series transformations. - Oecologia 179: 15-28.

CsóKA GY. 1997: Increased insect damage in Hungarian forests under drought impact. - Biologia 52: 159-162.

Dobbertin M., Wermelinger B., Bigler C., Bürgi M., Carron M., Forster B., Gimmi U. \& Rigling A. 2007: Linking increasing drought stress to scots pine mortality and bark beetle infestations. - Sci. World J. 7: 231-239.

Dingman S.L., Seely-Reynolds D.M. \& Reynolds R.C. 1988: Application of kriging to estimating mean annual precipitation in a region of orographic influence. - J. Am. Water Resour. Assoc. 24: 329-339.

Garen D.C., Johnson G.L. \& Hanson C.L. 1994: Mean areal precipitation for daily hydrologic modeling in mountainous regions. - J. Am. Water Resour. Assoc. 30: 481-491.

GotTschling S. \& MeYer S. 2006: An epidemic airborne disease caused by the oak processionary caterpillar. - Pediat. Dermatol. 23: 64-66.

GREEN P. 2015: Oak processionary moth (Thaumetopoea processionea) in deer parks. - Veter. Record 177: 208-208.

Groenen F. 2010: Variation of Thaumetopoea processionea (Notodontidae: Thaumetopoeinae) in Europe and the Middle East. - Entomol. Ber. 70: 77-82.

Groenen F. \& Meurisse N. 2012: Historical distribution of the oak processionary moth Thaumetopoea processionea in Europe suggests recolonization instead of expansion. - Agr. For. Entomol. 14: 147-155.

Hevesi J.A., Flint A.L. \& Istok J.D. 1992: Precipitation estimation in mountainous terrain using multivariate geostatistics. Part II: Isohyetal maps. - J. Appl. Meteorol. 31: 677-688.

Hirka A., Szabóky Cs., SzÖcs L. \& CsóKa Gy. 2011: 50 years of the forestry light trap network. — Növényvédelem 47: 474-479 [in Hungarian].

Hlásny T., Mátyás Cs., Seidl R., Kulla L., Merganičová K., Trombik J., Dobor L., Barcza Z. \& KonÔPKA B. 2014: Climate change increases the drought risk in Central European forests: What are the options for adaptation? - For. J. 60: 5-18.

Hlásny T., Trombik J., Holuša J., Lukášová K., Grendér M., TurČÁni M., Zúbrik M., Tabaković-Tošı́́ M., Hirka A., BuKSHA I., Modlinger R., KACPRZYK M. \& CSÓKA Gy. 2015: Multidecade patterns of gypsy moth fluctuations in the Carpathian
Mountains and options for outbreak forecasting. - J. Pest Sci. 89: 413-425.

Hoch G., Toffolo E.P., Netherer S., Battisti A. \& Schopf A. 2009: Survival at low temperature of larvae of the pine processionary moth Thaumetopoea pityocampa from an area of range expansion. - Agr. For. Entomol. 11: 313-320.

Hudson P.J., Dobson A.P. \& LAFFerTy K.D. 2006: Is a healthy ecosystem one that is rich in parasites? - Trends Ecol. Evol. 21: 381-385.

Jactel H., Petit J., Desprez-Loustau M.L., Delzon S., Piou D., Battisti A. \& Koricheva J. 2012: Drought effects on damage by forest insects and pathogens: A meta-analysis. - Glob. Change Biol. 18: 267-276.

JEFFS C.T. \& Lewis O.T. 2013: Effects of climate warming on host-parasitoid interactions. - Ecol. Entomol. 38: 209-218.

Jepsen J.U., Hagen S.B., Ims R.A. \& Yoccoz N.G. 2008: Climate change and outbreaks of the geometrids Operophtera brumata and Epirrita autumnata in subarctic birch forest: Evidence of a recent outbreak range expansion. - J. Anim. Ecol. 77: 257-264.

Jönsson A.M., Appelberg G., Harding S. \& Bärring L. 2009: Spatio-temporal impact of climate change on the activity and voltinism of the spruce bark beetle, Ips typographus. - Glob. Change Biol. 15: 486-499.

KalinKat G. \& Rall B.C. 2015: Effects of climate change on the interactions between insect pests and their natural enemies. In Björkman C. \& Niemala P. (eds): Climate Change and Insect pests. CABI, Wallingford, pp. 74-91.

KlapwiJk M.J., Csóka Gy., Hirka A. \& Bü̈RKMAn C. 2013: Forest insects and climate change: Long-term trends in herbivore damage. - Ecol. Evol. 3: 4183-4196.

LaKatos F. \& Molnár M. 2009: Mass mortality of beech (Fagus sylvatica L.) in South-West Hungary. - Acta Silvat. Lignar. Hungar. 5: 75-82.

LesKó K., SZEnTKIRÁLyi F. \& KÁdÁr F. 1994: Fluctuation patterns of the gypsy moth (Lymantria dispar L.) population between 1963-1990 in Hungary. — Erdész. Kutat. 84: 163-176 [in Hungarian].

Leskó K., SzentKirályi F. \& KádÁR F. 1995: Long term fluctuation pattern of the brown-tale moth (Euproctis chrysorrhoea L.) Hungarian population. - Erdész. Kutat. 85: 169-185 [in Hungarian].

Leskó K., SzentKiRÁlyi F. \& KÁdÁr F. 1997: Long term (19621996) fluctuation of the lackey moth population in Hungary. - Erdész. Kutat. 86-87: 207-220 [in Hungarian].

Leskó K., SzentKirályi F. \& KÁdÁr F. 1998: An analysis of fluctuation pattern of geometrid moths based on long term (19611997) light trap and damage data time series in Hungary. Erdés. Kutat. 88: 319-333 [in Hungarian].

LEskó K., SzentKIRÁlyi F. \& KÁdÁR F. 1999: Characterisation of the long term (1962-1997) fluctuation of winter moth (Operophtera brumata L.) population based on forestry light trap data. —Erdész. Kutat. 89: 169-182.

Li S., Daudin J.J., Piou D., Robinet C. \& Jactel H. 2015: Periodicity and synchrony of pine processionary moth outbreaks in France. - For. Ecol. Manag. 354: 309-317.

LiebHold A., Koenig W.D. \& BJøRnstad O.N. 2004: Spatial synchrony in population dynamics. - Annu. Rev. Ecol. Evol. Syst. 35: 467-490.

LiebHold A.M., Johnson D.M. \& BJøRnstad O.N. 2006: Geographic variation in density-dependent dynamics impacts the synchronizing effect of dispersal and regional stochasticity. Popul. Ecol. 48: 131-138.

LöVgren R. \& Dalsved B. 2005: Thaumetopoea processionea L. (Lepidoptera: Thaumetopoeidae) found in Sweden. — Entomol. Tidskr. 126: 93-94. 
Maier H., Spiegel W., Kinaciyan T. \& Hönigsmann H. 2004: Caterpillar dermatitis in two siblings due to the larvae of Thau metopoea processionea L., the oak processionary caterpillar. - Dermatology 208: 70-73.

MAtTSON W.J. \& HAACK R.A. 1987: Role of drought in outbreaks of plant-eating insects. Drought's physiological effects on plants can predict its influence on insect populations. - BioScience 37: 110-118.

McManus M. \& CsóKA Gy. 2007: History and impact of gypsy moth in North America and comparison to recent outbreaks in Europe. - Acta Silv. Lign. Hung. 3: 47-64.

Meurisse N., Hoch G., Schopf A., Battisti A. \& Grégoire J.-C. 2012: Low temperature tolerance and starvation ability of the oak processionary moth: implications in a context of increasing epidemics. - Agr. For. Entomol. 14: 239-250.

Mindlin M.J., Polain O., Waroux D., Case S. \& Walsh B. 2012: The arrival of oak processionary moth, a novel cause of itchy dermatitis, in the UK: Experience, lessons and recommendations. - Publ. Health 126: 778-781.

Mirchev P., Georgiev G., Georgieva M. \& Bocheva L. 2016: Impact of low temperatures on pine processionary moth (Thaumetopoea pityocampa) larval survival in Bulgaria. - Silva Balcan. 17: 51-58.

Moran P. 1953: The statistical analysis of the Canadian Lynx cycle. - Austral. J. Zool. 1: 291-298.

NowinszKY L. \& PusKás J. 2017: Light-trap catch of insects in connection with environmental factors. In Shields V.D.C. (ed.): Biological Control of Pest and Vector Insects. InTech, London, pp. 97-118.

NowinszKy L., PusKás J. \& Kúti Zs. 2010: Light trapping as a dependent of moonlight and clouds. - Appl. Ecol. Environ. Res. 8: 301-312.

Pelini S.L., Prior K.M., Parker D.J., Dzurisin J.D.K., Lindroth R.L. \& Hellmann J.J. 2009: Climate change and temporal and spatial mismatches in insect communities. In Letcher T. (ed.): Climate Change: Observed Impacts on Planet Earth. 1st ed. Elsevier, Oxford, pp. 215-231.

Pimentel C., Calvão T., Santos M., Ferreira C., Neves M. \& NiLsson J.Å. 2006: Establishment and expansion of a Thaumetopoea pityocampa (Den. \& Schiff.) (Lep. Notodontidae) population with a shifted life cycle in a production pine forest, Central-Coastal Portugal. — For. Ecol. Manag. 233: 108-115.

Pimentel C., Calvão T. \& Ayres M.P. 2011: Impact of climatic variation on populations of pine processionary moth Thaumetopoea pityocampa in a core area of its distribution. - Agr. For. Entomol. 13: 273-281.

PÖdÖr Z., EdelÉNyI M. \& Jereb L. 2014: Systematic analysis of time series. - Infocommun. J. 6: 16-21.

Raimondo S., Strazanac J.S. \& Butler L. 2004: Comparison of sampling techniques used in studying Lepidoptera population dynamics. - Environ. Entomol. 33: 418-425.

Rasztovits E., Berki I., Mátyás C., Czimber K., Pötzelsberger E. \& MórICZ N. 2014: The incorporation of extreme drought events improves models for beech persistence at its distribution limit. - Ann. For. Sci. 71: 201-210.

Robinet C. \& Roques A. 2010: Direct impacts of recent climate warming on insect populations. - Integr. Zool. 5: 132-142.

Roques A., Rousselet J., Avci M., Avtzis D.N., Basso A., Battisti A., Ben J.M.L., Bensidi A., Berardi L., Berretima W. et AL. 2015: Climate warming and past and present distribution of the processionary moths (Thaumetopoea spp.) in Europe, Asia Minor and North Africa. In Roques A. (ed.): Processionary Moths and Climate Change: An Update. Springer, Dordrecht, pp. 81-161.
Rouault G., Candau J.-N., Lieutier F., Nageleisen L.-M., MarTIN J.-C. \& WARZÉE N. 2006: Effects of drought and heat on forest insect populations in relation to the 2003 drought in Western Europe. - Ann. For. Sci. 63: 613-624.

Skule B. \& Vilhelmsen F. 1997: Thaumetopoea processionea L. found in Denmark. URL: http://www.lepidoptera.dk/process. htm (last accessed 30 May 2017).

Stigter H. \& Romeis G. 1992: [After a little more than a century Thaumetopoea processionea has again a massive local representation in The Netherlands.] — Entomol. Ber. (Amsterdam) 55: 9-66 [in Dutch].

Straw N.A. \& Williams D.T. 2013: Impact of the leaf miner $\mathrm{Ca}$ meraria ohridella (Lepidoptera: Gracillariidae) and bleeding canker disease on horse-chestnut: Direct effects and interaction. - Agr. For. Entomol. 15: 321-333.

SzONTAGH P. 1975: The role of light traps in the prognosis of forest pests. - Növényvédelem 11: 54-57 [in Hungarian].

SzONTAGH P. 1976: Gradation conditions of oak damaging macrolepidoptera. - Erdész. Kutat. 72: 63-68 [in Hungarian].

TAllós P. 1966: The role of light traps in forest protection. - $A z$ Erdö 15: 134-136 [in Hungarian].

Vanhanen H., Veteli T.O., Paivinen S., Kellomaki S. \& Niemela P. 2007: Climate change and range shifts in two insect defoliators: gypsy moth and nun moth - A model study. - Silva Fenn. 41: 621-638.

Wagenhoff E. \& Veit H. 2011: Five years of continuous Thaumetopoea processionea monitoring: tracing population dynamics in an arable landscape of South-Western Germany. - Gesun. Pfl. 63: 51-61.

Wagenhoff E., Blum R., Engel K., Veit H. \& Delb H. 2013: Temporal synchrony of Thaumetopoea processionea egg hatch and Quercus robur budburst. - J. Pest Sci. 86: 193-202.

Wagenhoff E., Wagenhoff A., Blum R., Veit H., Zapf D. \& Delb H. 2014: Does the prediction of the time of egg hatch of Thaumetopoea processionea (Lepidoptera: Notodontidae) using a frost day/temperature sum model provide evidence of an increasing temporal mismatch between the time of egg hatch and that of budburst of Quercus. - Eur. J. Entomol. 111: 207-215.

YAnG X., TANG G., XIAO C. \& Deng F. 2007: Terrain revised model for air temperature in mountainous area based on DEM1s. $-J$. Geogr. Sci. 17: 399-408.

YeLA J.L. \& HoLYOAK M. 1997: Effects of moonlight and meteorological factors on light and bait trap catches of noctuid moths (Lepidoptera: Noctuidae). — Environ. Entomol. 26: 283-1290.

Received September 26, 2017; revised and accepted May 9, 2018 Published online June 1, 2018

Table S1. Yearly OPM catches in the three light traps.

\begin{tabular}{lrrr}
\hline Year & Acsád & Sopron & Szalafö \\
\hline 1998 & 2 & 0 & 0 \\
1999 & 1 & 0 & 2 \\
2000 & 1 & 1 & 5 \\
2001 & 50 & 27 & 36 \\
2002 & 294 & 154 & 279 \\
2003 & 66 & 53 & 131 \\
2004 & 20 & 13 & 4 \\
2005 & 20 & 13 & 12 \\
2006 & 64 & 1 & 0 \\
2007 & 316 & 27 & 0 \\
2008 & 28 & 7 & 3 \\
2009 & 155 & 0 & 0 \\
2010 & 47 & 5 & 6 \\
2011 & 0 & 2 & 0 \\
2012 & 56 & 11 & 5 \\
Average & 75 & 21 & 32 \\
\hline
\end{tabular}

